Brit. J. prev. soc. Med. (1975), 29, 65-72

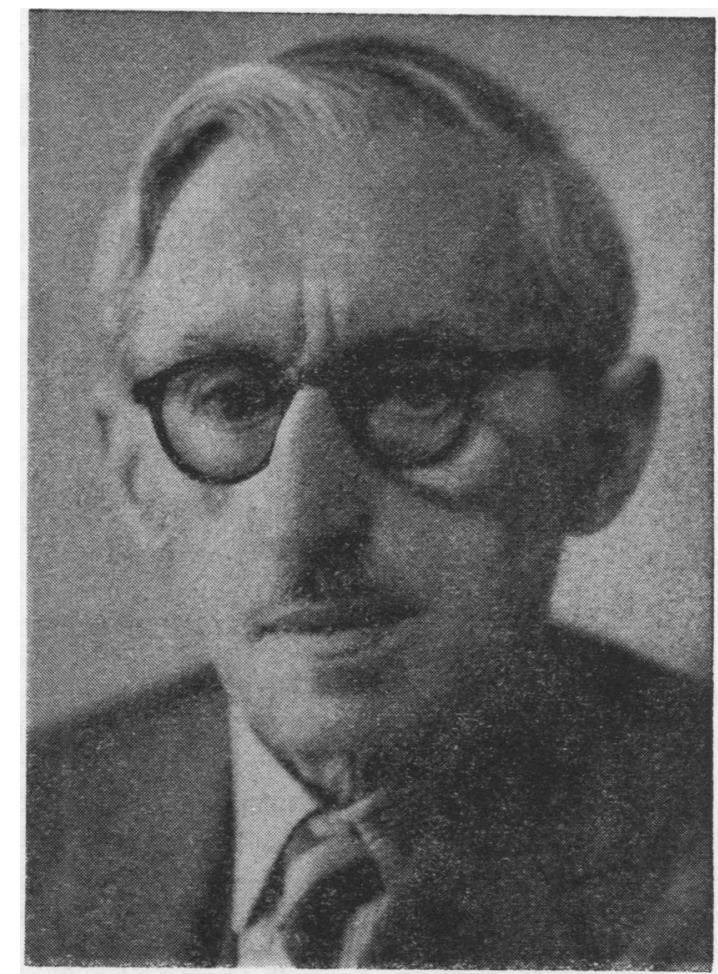

PerCy Stocks. CMG, MD Cantab., FRCP, DPH, HON.FFCM (1889 - 1974)

\title{
Percy Stocks: an appreciation
}

Dr. Percy Stocks's writing covered innumerable aspects of social and preventive medicine, and his contributions to medical literature opened up many topics which have since become important matters of debate. Because these papers amply repay study and are perhaps not as well known as they should be, the Editorial Board agreed that a bibliography of his works should be presented to our readers. We are grateful to Professor D. D. Reid, Dr A. M. Adelstein, and Dr W. P. D. Logan for contributing the following appreciations of Stocks's work as chief medical statistician at the General Register Office and as an international consultant.

BY D. D. REID

Percy Stocks's early work reflected his exposure to the stimulus and teaching of the remarkable group of men in the Galton Laboratory at University College that centred on Karl Pearson. Numerical methods in medicine were not new, for Farr had already demonstrated how vital statistics could contribute to medical science. But the potential of the powerful analytical techniques in biometry that were being forged by Pearson and his school was quickly appreciated by medical men like Greenwood and Stocks. It was perhaps hardly surprising that Stocks's first essays in this field were dictated by the genetic and biometric interests of the Galton Laboratory. Later, however, he returned to his essential concern with epidemiology and public health. In collaboration with Mary Karn, he applied mathematical and statistical methods of analysis to the study of outbreaks of measles in London. 
He was able to show that the epidemic phenomena involved could be explained by changes in the immunity state of the child population and by the influence of weather and other environmental factors on the ease of transmission of infection. Stocks then extended his approach to other specific fevers by his work on infectiousness and immunity in respect of chicken-pox, scarlet fever, whooping cough, and diphtheria and on the spread of smallpox in partially vaccinated communities.

Stocks was one of the first to carry over many of the concepts and methods of epidemiology from the acute infections to the chronic diseases of middle and late life. He applied theoretical models of disease behaviour to the age patterns of cancer of the stomach in 1953 and of cancer of the lung in 1966. Subsequent major developments in this field on the relation of duration of smoking to the risk of malignant disease thus owe much to this original work. Stocks also used sophisticated methods to dispose of the notion that there were 'cancer houses' by showing that the spacing of cases simply reflected the degree of aggregation of people of similar age in the same area. Much of this work is relevant to current discussions of the time-space relationships of malignant disease.

Geographical studies of the distribution of mortality were one of Stocks's special and enduring interests. His monograph on local cancer death rates published in 1947 was a text the fascinating contents of which were obscured by a drab title. Stocks was adept at pointing out the oddities in disease experience that hinted at possible causes; and he was quite prepared to push speculation beyond the conventional views of his time. He was the sentinel on the wall who alerted the Medical Research Council to the increasing menace of lung cancer and he certainly appreciated the overwhelming effect of smoking. But he also pointed out that air pollution in British cities might be responsible for their high death rates from lung cancer. By studies of international vital statistics and field studies in north-west England and Wales he produced evidence on the subsidiary effect of air pollution that is difficult to ignore. In the same way, he pin-pointed areas of excessive cancer mortality such as cancer of the stomach in north Wales or in the valley of the River Lea in north London and postulated the carcinogenic effect of some element in the soil or water supply. What may have sounded far-fetched in 1947 is now increasingly recognized as a practical possibility; and Stocks's demonstration in 1937 of an association between water hardness and mortality from renal calculus and cancer of the bladder, and in 1973 of its relation to cancer of the stomach and other conditions, is typical of an initiative that is reflected in current epidemiological pre- $\mathbb{\Phi}$ occupations, particularly in the field of cardio-? vascular disease.

In all this, Stocks displayed a fine balance of $\frac{\mathcal{O}}{0}$ scientific qualities. He was well fitted, by intellect $\frac{\square}{\sigma}$ and training, to apply the technical methods of $\frac{\bar{c}}{\bar{c}}$ statistical analysis. He also knew the limitations of $\vec{\Phi}$ vital statistical data and exercised caution and dis- $\frac{\varrho}{\sim}$ crimination in deriving conclusions from his work. ${ }^{\infty}$ On the other hand, he had the supreme advantages $\overrightarrow{0}$ of imagination and intellectual courage, which his $\vec{\overrightarrow{ }}$ modest and almost diffident exterior belied. In $\omega_{\sigma}^{\omega}$ pursuit of his personal ideal of the mitigation of $\frac{\bar{\phi}}{}$ the ravages of epidemic disease, he was prepared $\stackrel{?}{?}$ to speculate on causes and cures apparently without fear of being dismissed as an impractical visionary. $\dot{i}$

Many of Stocks's intriguing findings for example, or on the changes in mortality from diabetes ino war-time, have not been properly followed through. $\rightarrow$ His papers thus represent a treasury of epidemio- $c$ logical ideas that every intending investigator should raid. In retrospect, Stocks's speculations may not ${ }_{\vec{\Phi}}$ have always proved correct but, in his field of vital statistics, his knowledge, imagination, and insight. were unrivalled. To him, Paget's description gf Darwin could therefore justly apply: 'He hadj the rare power of taking the common things that other men waste, and out of them making the grandest material of scientific work'.

\section{By A. M. Adelstein}

Percy Stocks is justly renowned for many reasons, but probably mainly for the wide sweep of his work at the General Register Office (GRO). This work ushered in the second distinct period in the develop-: ment of epidemiology and vital statistics. The 3 . public health movement of the nineteenth century had been under-pinned by the magnificent system $₹$ of vital statistics created and managed by Williamo Farr. By giving the system its second wind Stocks helped significantly to develop the modern approacho to social medicine.

His work spanned some important landmarks N in medicine, and his prolific writing shows clearly how well he understood them. He came to then Registrar General's Office in 1933 and his early ${ }_{\sigma}^{\omega}$ papers revealed his interest in developing the standard analysis of vital records; he had already produced an example of a retrospective study,, ? with controls, to investigate the environmental contribution to cancer.

In another paper he gives a careful analysis of the effects on longevity of the two great therapeutic discoveries of the time, the treatment of diabetes 
and of pernicious anaemia. This paper has a masterly discussion of how patients could be expected to accept the treatment, of how their deaths would be postponed, and of the effects on vital statistics. He concluded that two years after the introduction of liver therapy in 1926 there was a fall of $35 \%$ in the death rate from pernicious anaemia, but that by 1932 the postponed deaths of all the patients had masked these gains in older persons. He estimated the average lengthening of life in England and Wales of all persons afflicted with pernicious anaemia at 3 to $3 \frac{1}{2}$ years, compared with about 8 years for those who were treated. A similar analysis for diabetes was more difficult because here the mortality rate was increasing; nevertheless he concluded that the average life of a diabetic had been extended by nearly $3 \frac{1}{2}$ years.

This paper shows that Stocks was interested in widening the use of traditional records, and in fact during the rest of his career he was responsible, by his initiative and involvement, for a great expansion in the medical activities at the GRO. In all this he was not working alone, of course, but I hope that others will forgive the omission of their names from this tribute.

His guiding hand is evident in a whole series of sets of records, including the Survey of Sickness, the Hospital In-patient Enquiry (HIPE), the Cancer Registry, and the Mental Health Enquiry. He anticipated the need for a comprehensive medical information system, and for this he obtained the co-operation and the confidence of the Department of Health, the Medical Research Council (MRC), and other leading medical institutions and practitioners.

He himself did most of the work of planning, designing, and analysing the initial results. His introductions to the published results are models of clear thinking and any student of epidemiology would do well to study them.

Although busy innovating, he did not neglect the study and development of traditional vital statistics. He wrote papers to warn the profession of the growing scourges of our times-coronary heart disease and cancer of the lung-inferring from a close examination of occupational mortality statistics that lack of exercise might be a factor in coronary heart disease. He noted that women of the higher social classes suffered more breast cancer than others. In 1935, in an elegant analysis, he showed how influenza was an important cause of death, noting that it often precipitated deaths from other diseases, particularly heart disease.

Percy Stocks had the unusual gift of being able to interpret his own times, often showing the way to the future of social medicine. As early as 1944 he wrote: 'The conquest of acute diseases is likely to continue with increasing rapidity and consequently chronic degenerative diseases will assume greater importance in the general morbidity picture. It is improbable that such conditions will respond greatly to chemotherapy; it is more likely that we shall have to go back to their beginnings and try to remove or counteract the irritant causes which, when unchecked, eventually produce them'.

His success owed much to his ability to distinguish the important data and methods, and to avoid the lure of trivia. Amidst this veritable avalanche of analyses, it is not surprising that sometimes his deductions were speculative and that sometines his enthusiasm for the advancement of social medicine overran itself. In the paper quoted above, developing the subject of continuous health histories, he said: 'In my opinion it should be started forthwith for every newborn child, with, as first suggested, the keeping of continuous records of every event directly or indirectly affecting the child's health up to the age of 15 . We may anticipate that before the children now being born have reached that age, a National Health Service will have been developed which could continue to take care of their records throughout life'.

This was starry-eyed and well ahead of its time. We still talk like this today seated astride our computers but we have not done much about it; we are busy looking for answers to the same questions on epidemiology; we still have not reached his (or Farr's) ideal system in which records of important events in every person's life are brought together.

As had happened before, the second world war concentrated the nation's mind on the problems of health; Percy Stocks's work in the GRO became a focal point for these studies. He regularly reported his careful analyses of the vital statistics, ever watchful for new ways of monitoring health. With the Government Social Survey he developed the Survey of Sickness. He aimed apparently at an Index of Morbidity, a single statistical measure of the health of the community, taking account of death and serious, moderate, and minor illness. Using war-time certificates of Priority Allowance of Foods, he analysed the effect of the war on diabetes, thyrotoxicosis, tuberculosis, and peptic ulcer.

In 1944 he analysed 'hepatitis and jaundice amongst the emergency medical service hospital in-patients' saying 'for some diseases old-standing beliefs about aetiology have been blown to pieces in the present war, and the jaundice group has suffered more disturbance, perhaps, than any. 
As late as 1938 "catarrhal jaundice" was comfortably housed amongst diseases of the bile ducts'.

Colleagues, both outside and in the GRO, speak fondly of the man Stocks; among his virtues they praise his working style, how quickly he got down to a job, and how much of the basic work he did himself.

So it is not surprising to find that following the tradition of Farr he contributed greatly to the construction of disease classifications, especially the adaptation of the International Classification of Diseases (ICD) so that it would serve both for morbidity and general medical use as well as for mortality. This essential tool of epidemiology, though apparently simple and surrounded by selfappointed experts, really needed all the hard-earned experience and dedication of someone like Percy Stocks to unravel its complexity and guide its development.

Percy Stocks did very well in steering the GRO into the era of social medicine, and for long after he left the GRO in the year 1951 he continued to give his valuable experience to the World Health Organisation (WHO), and until recently he was still using his expertise on the current statistics of the GRO, regularly producing important papers. I have enjoyed reading his papers for this review, some for the first time. They reveal him as a modest man, and I fancy their tone reflects his times-less exuberant and more restrained than Farr; addressed less to the world at large and more to the medical profession; without the excitement of the industrial revolution and great reforms but with the self-conscious atmosphere of the two world wars. As one of his close colleagues said 'he was cool, objective, warm underneath, and always ready to look objectively at health questions'.

\section{By W. P. D. Logan}

The day I joined the GRO in May 1948 Percy Stocks had just come back from Paris where he had played a leading role in the international revision conference of $I C D$-the Sixth Revision, which was memorable in that it heralded the turning over of responsibility for the decennial revision from the Government of France to the WHO. Stocks had been working on the new revision for several years as Chairman of the preparatory committee, and had been to the USA and Canada to discuss his ideas which were accepted there without opposition. His leadership and authority in $I C D$ and what it meant was unquestioned, both within the WHO and outside.
I did not accompany him to the Paris meeting in April 1948 but I am told that the moment the conference finished and the UK delegation set off? to the Gare du Nord, Stocks spent an hour or two in the waiting room with a writing pad on his lap $\stackrel{?}{+}$ drafting the next issue of the Registrar General's 'Text', while the rest of the delegates spent their $\frac{\bar{c}}{\bar{c}}$ time in less constructive activities.

In July 1948 he was off to the first World Health Assembly to make sure that his Sixth Revision of $I C D$ was properly adopted without uninformed $\overrightarrow{0}$ modification or obstruction. The ignorance was $\overrightarrow{-}$ enormous-Stocks could hardly believe it, he said- $\bar{\omega}$ but everything went all right and ICD/6 was officially adopted by the WHO. The Third World? Health Assembly in 1950 was the last he attended. if Nonetheless, the contact he had had with WHO $_{j}^{\circ}$ had given him a great awareness of world healtho problems, as was demonstrated by his discussion. of population, nutrition, and disease in a lecture on? statistics and world health that he gave in Michigan $\vec{c}$ in 1949.

Soon after he had retired from the GRO, he was ${ }_{-}$ appointed head of the newly established Centre $\varphi$ for Classification of Diseases in the GRO brangh. office in Southport, Lancashire. The Centre was fact created so that Stocks could continue to gizes advice on what $I C D / 6$ was all about and how it was to be used. He was the unnamed author of

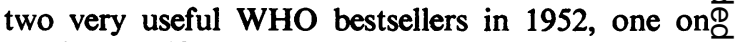
medical certification of cause of death, and the other $\overrightarrow{\vec{P}}$ on comparability between the Fifth and Sixth 3 revisions of $I C D$.

WHO has a number of panels of experts, and one of these is the Expert Panel on Health Statistics. Stocks was one of the very first WHO experts and stayed on the panel until February 1972 when, at the age of 82 , it seemed time to let him withdraw, especially since the usual age limit is about 65 .

In his capacity as a WHO expert, he attended a series of WHO Expert Committee meetings ono Health Statistics during WHO's formative years between 1948 and 1953, sometimes as chairman, and repeatedly came to the aid of the secretariat by indicating very clearly what was wanted. $\mathrm{He}^{\mathrm{G}}$ was also a regular participant in WHO's Sub- N committee on Cancer Statistics, a field that had been N of special interest to him throughout his workingo life but which concerned him most in the decade between the late fifties and late sixties.

Stocks did not by any means confine himself? to cancer studies during this period but served as 0 a consultant to the Pan American Health Organi-o zation and helped Ruth Puffer with her pioneer survey of urban mortality in the Americas. He worked高 
out a novel weighting scheme for the coding of the death certificates and together with Dario Curiel from Caracas coded the 20000 records that were analyses in the investigation. He did some of this in Washington until Mrs Stocks decided that he should not make such long journeys, so we gave him an office in the Palais des Nations in Geneva where he spent weeks steadily ploughing through those thousands of records. It was characteristic of him that he insisted on there being two consultants to do the job-not because he needed or wanted help but because, since coding continuity and uniformity was essential, the investigation should not put all its reliance on the survival of one consultant aged over 70 .

That was over 10 years ago. Up to last year he was still publishing good papers that are read with admiration for their originality and lucidity. His contribution to epidemiology and to health statistics has been immeasurably great. Both the WHO and the health of the world have benefited enormously from his life's work, and I who was his disciple and his colleague am grateful for all he did.

\section{BiBLIOGRAPHY}

\section{InCLUding SOME ANONYMous RePorts}

(1916) The quantative determination of amylase in blood serum and urine as an aid to diagnosis. Quart. J. Med., 9, 216.

(1919) Experiments on the action of unsaturated fatty acids and lipoids. J. Path. Bact., 23, 1. Annual Report of Acting School Medical Officer for 1918. Bristol.

(1923) Facial spasm inherited through four generations. Biometrika, 14, 311.

On an unusual case of digital anomaly. Biometrika. 14, 410. (Jointly with Karl Pearson.)

On the inheritance of cranial anomalies. Biometrika, 15, 406.

(1924) Blood Pressure in Early Life. Cambridge University Press.

Cancer and goitre. Biometrika, 16, 364.

(1925) Some further notes on cancer and goitre distributions. Biometrika, 17, 159.

Hereditary Disorders of Bone Development. Cambridge University Press.

(1926) On the influence of sanatorium and dispensary treatment and housing conditions on pulmonary tuberculosis. Ann. Eugen. (Lond.), 1, 407.

(1927) Goitre in adolescence. Biometrika, 19, 292.

On the relation between the prevalence of thyroid enlargement in children and mortality from cancer and other diseases. Ann. Eugen. (Lond.), $2,395$.
On the influence of iodine administration on goitre incidence and physical growth in adolescent girls. Ann. Eugen. (Lond.), 2, 382.

Fresh evidence on the inheritance factor in tuberculosis, Part 1. Ann. Eugen. (Lond.), 2, 41.

(1928) Goitre in the English school child. Quart J. Med., 21, 223.

Fresh evidence on the inheritance factor in tuberculosis, Part 2. Ann. Eugen. (Lond.), 3, 84. Infant mortality in the metropolitan boroughs in relation to occupation. Ann. Eugen. (Lond.), 3, 192.

On the evidence for a regional distribution of cancer in England and Wales. Report of the International Conference on Cancer, 1928. Pp. 508-519. On the value of the statistical method in practical medicine. Lancet, 1, 1242.

A study of the epidemiology of measles. Ann. Eugen. (Lond.), 3, 361.

(1929) Some pitfalls in the statistical study of tuberculosis. Brit. J. Tuberc., 23, 169.

(1930) The mechanism of a measles epidemic. Lancet, $1,796$.

Infectiousness and immunity in regard to chickenpox, whooping cough, diphtheria, scarlet fever and measles. Proc. roy. Soc. Med., (Section of Epidemiology), 1349.

A biometric investigation of twins and their brothers and sisters, Part 1. Ann. Eugen. (Lond.), 4, 49.

(1931) The distribution of cancer and tuberculosis mortality in England and Wales. Ann. Eugen. (Lond.), 4, 341.

Some observations on the control of measles epidemics. Brit. med. J., 2, 977.

(1932) On the incidence of encephalitis lethargica and acute anterior poliomyelitis in Lancashire and elsewhere. J. Hyg. (Lond.), 32, 219.

The control of measles and whooping cough. $J$. Inst. Hyg., 6.

On the epidemiology of whooping cough in London. J. Hyg. (Lond.), 32, 581.

(1933) A biometric investigation of twins and their brothers and sisters, Part 2. Ann. Eugen. (Lond.), $5,1$.

Race and climate as possible factors. In: Arteriosclerosis. A survey of the Problem, chap. 7. MacMillan, New York.

On the spread of smallpox in partially vaccinated communities, Part 1. Ann. Eugen. (Lond.), 5, 192.

On the spread of smallpox in partially vaccinated communities, Part 2. Ann. Eugen. (Lond.), 5, 302. Some epidemiological features of whooping cough. Lancet, 1, 213; 265.

Latent immunisation in measles. Lancet, 1, 1086. A co-operative study of the habits, home life, dietary and family histories of 450 cancer patients and of an equal number of control patients. Ann. Eugen. (Lond.), 5, 237. 
(1934) The association between mortality and density of housing. Proc. roy. Soc. Med., (Section of Epidemiology), 27, 1127.

(1935) The frequency of cancer deaths in the same house and in neighbouring houses. J. Hyg. (Lond.), $35,46$.

Vital statistics. In: Principles and Practice of Preventive Medicine, Vol. 2, edited by C. W. Hutt and H. H. Thomson, pp. 1530-77. Methuen, London.

The lengthening of life by modern therapy in pernicious anaemia and diabetes. Brit. med. J., 1013.

The effect of influenza epidemics on the certified causes of death. Lancet, 2, 386.

A comparison of mortality rates from bronchitis and pneumonia, and from respiratory tuberculosis in coal miners and other residents in the counties of Nottingham, Derby, Glamorgan and Monmouth, 1921-23. J. industr. Hyg., 17, 217.

(1936) Distribution in England and Wales of cancer of various organs, 13th Annual Report of British Empire Cancer Campaign. Pp. 257-274.

(1937) Maternal mortality according to number of previous confinements. Effects of social grade, twin pregnancy and the declining birth rate. Report of an Investigation into Maternal Mortality. Cmd.5422. Pp. 87-111.

Distribution in England and Wales of cancer of various organs, 14th Annual Report of British Empire Cancer Campaign. Pp. 198-223.

(1938) The effects of occupation and of its accompanying environment on mortality. J. roy. stat. Soc., 669.

(1939) Distribution in England and Wales of cancer of various organs, 16th Annual Report of British Empire Cancer Campaign. Pp. 308-343.

(1940) The first seven months: A study of war-time mortality in London. Lancet, 1, 725.

Morbidity and death rates in the great towns. Lancet, 2, 550.

(1941) Health indices for Greater London and New York, 1931-40. Brit. med. J., 96.

Vital statistics of the second year of the war. Lancet, 1, 189.

Diphtheria and scarlet fever incidence during the dispersal of 1939-40. J. roy. stat. Soc., 104, 311.

(1942) Measles and whooping cough incidence during the dispersal of 1939-41. J. roy. stat. Soc., 105, 259. Vital statistics of England and Wales in 1941. Brit. med. J., 789.

The Adolescent Criminal. Churchill, London. (Jointly with W. N. East and H. T. P. Young.)
(1943) Vital statistics of 1942. Lancet, 1, 672.

Notes on war time vital statistics. Diabetes mortality in 1838-42 compared with 1913-17.? Mth. Bull. Minist. Hlth Lab. Serv., 2, 90.

Notes on war time vital statistics. Causes of death $\stackrel{\vec{F}}{+}$ in March quarter. Mth. Bull. Minist. Hlth Lab. Serv., 2, 115.

Notes on war time vital statistics. Site-trends of $\frac{\bar{s}}{\frac{5}{5}}$ cancer mortality 1911-42. Mth. Bull. Minist. Hlth Lab. Serv., 2, 131.

(1944) Notes on war time vital statistics. Infant $\vec{O}$ mortality in Greater London and New York:Mth. Bull. Minist. Hlth Lab. Serv., 3, 7.

Notes on war time vital statistics. Hepatitis and jaundice amongst EMS hospital in-patients. January 1942-June 1943. Mth. Bull. Minist. Hlth? Lab. Serv., 3, 22.

Illegitimate births in 1939-43. Mth. Bull. Minist.iv Hlth Lab. Serv., 3, 55.

War-time incidence of and mortality from respiratory tuberculosis. Brit. med. J., 581. (Jointly with E. Lewis-Fanning.)

Health survey, November 1943-January 1944. Mth. Bull. Minist. Hlth Lab. Serv., 3, 70.

Health survey, December 1943-February 1944. $\overrightarrow{0}$ Mth. Bull. Minist. Hlth Lab. Serv., 3, 93. Mortality and morbidity in tuberculos Practitioner. (Symposium on Modern Problems in Tuberculosis.)

Notes on hepatitis and jaundice among EMS hospital in-patients (II). Mth. Bull. Minist.

Hlth Lab. Serv., 3, 115.

Vital statistics of 1943. Lancet, 2, 65.

The Incidence of Rickets in War-time. Ministry of Health and British Paediatric Association.

The measurement of morbidity. Proc. roy. Soc. Med., (Section of Epidemiology and State? Medicine) 37, 593.

Diabetes mortality in 1861-1942 and some of $\bigcirc$ the factors affecting it. J. Hyg. (Lond.), 43, 242. Morbidity statistics of respiratory tuberculosis. 3 . Mth. Bull. Minist. Hlth Lab. Serv., 3, 127.

Health survey, April-July 1944. Mth. Bull. Minist. Hlth Lab. Serv., 3, 194.

Causes of admission of service patients to EMS $\stackrel{\circ}{\triangle}$ Hospitals. Mth. Bull. Minist. Hlth Lab. Serv., 3, 216. I

(1945) Health survey, July-September 1944. Mth. Bull. Minist. Hlth Lab. Serv., 4, 30.

Vital Statistics, pp. 352-359. Wright, Bristol.

War-time injuries in England and Wales. Brit. med. J., 601.

(1946) The comparative mortality index. Mth. Bull. Minist. Hith Lab. Serv., 5, 149. Cancer mortality in England and Wales. Mth. Bull. Minist. Hlth Lab. Serv., 3, 172.

Vital Statistics, pp. 373-378. Wright, Bristol.

(1947) Comparative notification rates of diphtheria, scarlet-fever, measles and whooping cough. Mth. Bull. Minist. Hlth Lab. Serv., 6, 2. 
Tuberculosis death rates by sex and age, 1931-46. Mth. Bull. Minist. Hlth. Lab. Serv., 6, 24. Death rates from certain chronic diseases in the first half of 1946 and preceding years. Mth. Bull. Minist. Hlth Lab. Serv., 6, 26.

Vital Statistics, pp. 404-409. Wright, Bristol. Morbidity statistics. Publ. Hlth (Lond.), 60, 137. Regional and Local Differences in Cancer Death Rates. Studies on Medical and Population Subjects, No. 1. HMSO, London.

(1948) Survey of sickness prevalence, March quarter. Mth. Bull. Minist. Hlth Lab. Serv., 7, 213. Vital Statistics, pp. 360-364. Wright, Bristol. Statistics of the rheumatic diseases. In: Text Book of Rheumatic Diseases, edited by W. S. C. Copeman, chap. 30. Livingstone, London.

(1949) Study of tuberculosis mortality in England and Wales. Tubercle. (Edinb.), 50.

Sickness in the Population of England and Wales in 1944-47. Studies in Medical and Population Subjects, No. 2. HMSO, London.

Vital Statistics, pp. 397-402. Wright, Bristol.

Vital statistics, modern developments. In: Modern Trends in Public Health, edited by A. Massey, chap. 19. Butterworth, London.

(1950) Methods of measuring results in the treatment of cancer. J. Fac. Radiol. (Lond.), 1, 167.

Fifty years of progress as shown by vital stat istics. Brit. med. J., 54 and In: Fifty Years of Medicine, pp. 247-257. BMA, London.

Cancer of the stomach in the large towns of England and Wales, 1921-39. Brit. J.Cancer, 4, 147.

Morbidity statistics-do we want them? Amer. J. publ. Hlth. 40, 670.

Vital statistics of tuberculosis in England and Wales. Practitioner, 165, 212.

Contributions of statistics to world health. Bull. Wld Hlth Org., 2, 731.

Cancer Registration in England and Wales. Studies on Medical and Population Subjects, No. 3. HMSO, London.

Vital Statistics, pp. 379-383. Wright, Bristol.

(1951) Measurement of the public health. Brit. med. Bull., 7, 312.

Vital Statistics, pp. 355-359. Wright, Bristol.

Coronary disease and modern stress. Lancet, $1,351$.

(1952) Counting heads. Family Doctor, 2, 277.

Recent statistics of multiple births. Acta Genet. med. (Roma), 1, 8.

Cancer statistics. Chambers Encyclopaedia.

Endemiology of cancer of the lung in England and Wales. Brit. J. Cancer, 6, 99.

Air pollution and cancer of the lung. Smokeless Air, 60, and In: Proceedings of the Portsmouth Conference, pp. 17-20. National Smoke Abatement Society, London.
Medical Certification of Cause of Death and Comparability of Statistics of Causes of Death according to 5th and 6th Revisions of the International Classification. Suppl. 3 and 4. WHO. Vital Statistics, pp. 415-419. Wright, Bristol.

(1953) Statistics, medical. In: British Encyclopaedia of Medical Practice, 3rd edit. Butterworth, London. Studies of cancer death rates at different ages in England and Wales in 1921 to 1950; uterus, breast and lung. Brit. J. Cancer, 7, 283.

A study of the age curve for cancer of the stomach in connection with a theory of the cancer producing mechanism. Brit. J. Cancer., $7,407$.

(1954) Needs in vital and health statistics in underdeveloped countries. Bull. Wld Hlth Org., 11, 131.

(1955) Statistics of cancer of the lung. J. Fac. Radiol. (Lond.), 6, 166.

Social status in relation to carcinoma of the breast, Schweiz. Z. allg. Path., 17, 706.

Lung cancer death rates among non-smokers and pipe and cigarette smokers. Brit. med. J., 2, 923. (Jointly with J. M. Campbell.)

Physical activity and arteriosclerotic heart disease. Publ. Hlth Rep. (Wash.), 70.

Cancer of the uterine cervix and social conditions. Brit. J. Cancer, 9, 487.

(1956) Cancer death rates in Japan contrasted with those in England and Wales. Brit. J. Cancer, 10, 257.

(1957) Methodology of epidemiological studies of cancer. Acta Un. int. Cancr., 13, 86.

The epidemiology of cancer of the breast. Practitioner, 179, 233.

(1958) Statistical investigations concerning the causation of various forms of human cancer. In: Cancer, Vol III, edited by M. O. Raven, pp. 116-172. Butterworth, London.

Cancer mortality trends in England and Wales. In: Cancer, Vol. III, edited by M. O. Raven, pp. 186-220. Butterworth, London.

Cancer incidence in North Wales and Liverpool region in relation to habits and environment. British Empire Cancer Campaign. Suppl. to Annual Report for 1957. Pp. 1-156.

Air pollution and cancer mortality in Liverpool hospital region and North Wales. Int. J. Air Pollut., 1, 1.

(1959) Cancer and bronchitis mortality in relation to atmospheric deposit and smoke. Brit. med. J., $1,74$.

The epidemiology of cancer. Practitioner, 182, 667.

Cancer registration and studies of incidence by surveys. Bull. Wld Hlth Org., 20, 697. 
(1960) Epidemiological evidence from chemical and spectrographic analyses that soil is concerned in the causation of cancer. Brit. J. Cancer., 14, 8. (Jointly with R. I. Davies.)

A localised high incidence of gastric cancer. Publ. Hlth (Lond.), 74, 408. (Jointly with R. I. Davies.)

On the relations between atmospheric pollution in urban and rural localities and mortality from cancer, bronchitis and pneumonia, with particular reference to 3:4 benzopyrene, beryllium, molybdenum, vanadium and arsenic. Brit. $J$. Cancer, 14, 397.

Population studies in cancer. Acta Un. int. Cancr., $16,1676$.

(1961) A study of polycyclic hydrocarbons and trace elements in smoke in Merseyside and other northern localities. Int. J. Air Wat. Pollut., 4, 141. Some geographical, occupational and social factors predisposing to carcinoma of the oesophagus. In: Tumours of the Oesophagus, edited by N. C. Tanner and D. W. Smithers, pp. 37-53. Livingstone, London.

A study of cancer mortality in farming, quarrying, mining and other occupations in North Wales and Cheshire. Brit. J. Cancer, 15, 701.

(1962) Geographical pathology and water supplies. Med. Offr., 108, 356.

On the death rates from cancer of the stomach and respiratory diseases in 1949-53 among coal miners and other male residents in counties of England and Wales. Brit. J. Cancer, 16, 592.

(1964) Zinc and copper content of soils associated with the incidence of cancer of the stomach and other organs. Brit. J. Cancer, 18, 14. (Jointly with R. I. Davies.)
(1966) Recent epidemiological studies of lung cancer mortality, cigarette smoking and air pollution, with discussion of a new hypothesis of causation. Brit. J. Cancer, 20, 595.

(1967) Lung cancer and bronchitis in relation to cigarette smoking and fuel consumption in twenty countries. Brit. J. prev. soc. Med., 21, 181.

(1968) Indications of possible association between peptic ulcer and vascular lesions of the central nervous system. Brit. J. prev. soc. Med., 22, 206.

(1969) Female susceptibility to cancer and other diseases as indicated by British and European mortality rates. Brit J. Cancer, 22, 254.

(1969) Heart disease mortality in cities of Latin America and cities and regions of England and Wales. Bull. Wld Hith Org., 40.

of congenital malformations in the regions of England and Wales. Brit. J. prev. soc. Med., 24, 67.

Cancer mortality in relation to national consumption of cigarettes, solid fuel, tea and coffee. Brit. J. Cancer, 24, 215.

(1971) Multiple sclerosis distribution in England arfi Wales. J. Hyg. (Lond.), 42, 373. Urban variation in infant mortality from bir峦 injury and atelectasis in England and Wales 1957-63. J. Hyg. (Lond.), 70, 181.

(1973) Mortality from cancer and cardiovascular $\stackrel{\mathbb{Q}}{\unrhd}$ diseases in England and Wales classified according $\overrightarrow{\vec{F}}$ to the sources and hardness of their water supplies, 1958-1967. J. Hyg. (Lond.), 71, 236. 